\title{
Atomic Energy
}

\section{General}

Gowing, M. M., Britain and Atomic Energy 1939-45 (Macmillan, 1964). $464 \mathrm{pp}$.

Gowing, M. M., Independence and Deterrence: Britain and Atomic Energy 1945-52 (Macmillan, 1974). Two volumes.

Pocock, R. F., Nuclear Power - Its Development in the United Kingdom (Unwin Brothers, 1977). 263 pp.

Williams, Roger, The Nuclear Power Decisions: British Policies 1953-1978 (Croom Helm, 1980). 365 pp. 